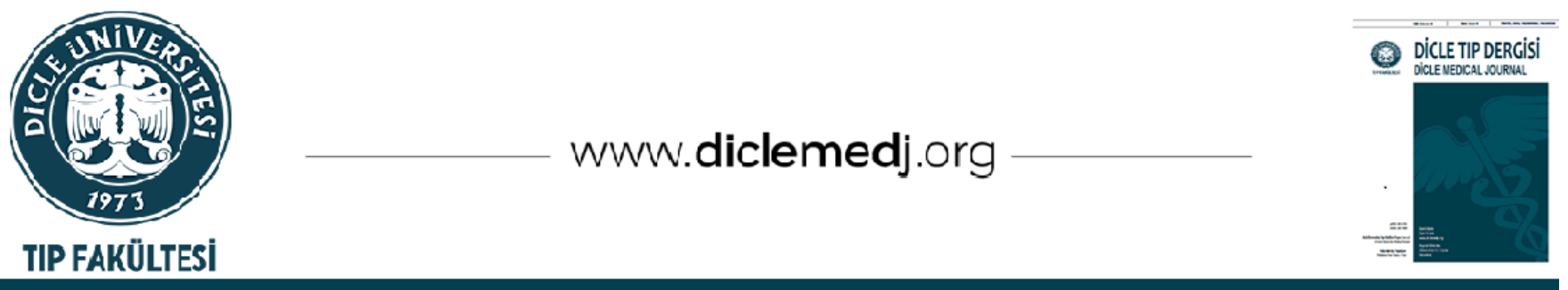

Original Article / Özgün Araştırma

\title{
Use of A New Extracorporeal Membran Oxygenator System and First Experiences
}

\author{
Servet Ergün ${ }^{1}{ }_{1}$, okan Yildiz ${ }^{1}$, Mustafa Güneş ${ }^{i}{ }_{1}$, Shiraslan Bakhshaliyev ${ }^{i}{ }_{1}$, Erkut Öztürk ${ }^{2}$, \\ İsmihan Selen Onan $D_{1}$, Alper Güzeltaş ${ }^{D}$, Sertaç Haydin ${ }^{D} 1$ \\ 1 Department of Cardiovascular Surgery, Istanbul Saglik Bilimleri University Istanbul Mehmet Akif Ersoy Thoracic and Cardiovascular Surgery Education \\ and Research Hospital, Istanbul, Turkey
}

2 Department of Pediatric Cardiology, Istanbul Saglik Bilimleri University Istanbul Mehmet Akif Ersoy Thoracic and Cardiovascular Surgery Education and Research Hospital, Istanbul, Turkey

Received: 19.06.2020; Revised: 30.11.2020; Accepted: 01.12.2020

\begin{abstract}
Objective: In this study, we aimed to share our first experiences about the extracorporeal membrane oxygenator (ECMO) system that we have just started to use and compare it with the system we used before.

Methods: Between January 2019 and December 2019, 27 consecutive patients under the age of 18 who were operated for congenital heart disease and needed ECMO support were retrospectively analyzed. İn this period The Medos Deltastream diagonal pump and Sorin Revolution ECMO systems were used.

Results: Successful wean was observed in six (42.9\%) patients in Medos ECMO group and two (15.4\%) in Sorin ECMO group. Five (35.7\%) patients discharged in the Medos ECMO group. In Sorin ECMO group all patients died. The difference between the groups in terms of the number of patients discharged was statistically significant $(p=0.02)$. Lactate clearance was 14 hours in Medos ECMO and 48 hours in Sorin ECMO ( $\mathrm{p}=0.02)$.

Conclusion: In this study, in which we shared our first experiences regarding the first use of the Sorin ECMO system in the postcardiac pediatric patient group, we observed slower lactate clearance, lower succesful wean and higher mortaly rates. Therefore, this should be taken into account during the use of this system.
\end{abstract}

Keywords: Extracorporeal, oxygenator, mortality, morbidity, Liliput, Hilite, Medos, Revolution

DOI: $10.5798 /$ dicletip.850129

Correspondence / Yazıșma Adresi: Servet Ergün, Department of Pediatric Cardiovascular Surgery, Istanbul Saglik Bilimleri University Mehmet Akif Ersoy Thoracic and Cardiovascular Surgery Education and Research Hospital, Istanbul, Turkey e-mail: drservetergun41@gmail.com 


\section{Farklı Bir Pediyatrik Extrakorporeal Membran Oksijenatör Sistemine Geçiş ve İlk Tecrübeler}

Öz

Giriş: Çalışmamızda yeni kullanmaya başladığımız extracorporeal membran oksijenatörü (ECMO) sistemi ile ilgili ilk tecrübelerimizi paylaşmak ve daha önce kullandığımız sistem ile kıyaslamayı amaçladık.

Yöntemler: Ocak 2019 ile Aralık 2019 tarihleri arasında kliniğimizde konjenital kalp hastalığı nedeni ile opere edilmiş ve sonrasında ECMO desteği ihtiyacı olmuş 18 yaş altı 27 ardışık hasta retrospektif olarak incelenmiştir. Belirtilen tarih aralığında The Medos Deltastream diagonal pump ve Sorin Revolution sistemi kullanılmıștır.

Bulgular: Medos ECMO kullanılan grupta başarılı wean altı (\%42.9) hastada gözlenirken, Sorin ECMO kullanılan grupta iki (\%15.4) olarak saptandı. Taburcu edilen hasta sayısı ise Medos ECMO kullanılan grupta beş (\%35.7) olarak saptandı. Sorin ECMO kullanılan hastaların tamamının ex olduğu gözlendi. Taburcu edilen hasta sayısı açısından gruplar arası fark istatistiksel anlamlı idi ( $\mathrm{p}=0.02)$. Laktat klirensi Medos ECMO' de 14 saat iken, Sorin ECMO' da 48 saat olarak saptandı $(\mathrm{p}=0.02)$.

Sonuç: Sorin ECMO sisteminin postkardiyotomi pediatric hasta grubunda kullanımına ilişkin ilk tecrübelerimizi paylaştığımız çalışmamızda, bu sistemde daha yavaş laktat klirensi, daha az başarılı wean ve daha az taburculuk oranları gözlemledik. Bu yüzden bu sistemin kullanılması sırasında bu faktörlerin göz önüne alınması gerektiği görüşündeyiz.

Anahtar kelimeler: Ekstrakorporeal, oksijenatör, mortalite, morbidite, Lilliput, Hilite, Medos, Revolution.

\section{INTRODUCTION}

Advances in the field of biotechnology are increasing day by day. There are also various innovations in extracorporeal membrane oxygenator (ECMO) systems and new centrifugal pumps, oxygenators are manufactured ${ }^{1,2}$. These include oxygenators that are more resistant to plasma leakage, heparin-coated circuits and centrifugal pumps that reduce hemolysis ${ }^{2}$. There are many ECMO systems combinations of commercially available pumps and oxygenators. However, the superiority of these systems in terms of the systemic inflammatory response, plasma leakage, hemolysis, and thrombosis is a matter of debate ${ }^{2-3}$.

In our study, we aimed to share our first experiences about the ECMO system that we have just started using (Sorin Revolution) and to compare it with the system we used before (Medos Deltastream diagonal pump).

\section{METHODS}

After approval of the ethics committee (permit no: 140919 date: 30.01.2020), 27 consecutive patients under 18 years of age who underwent an operation for congenital heart disease and needed ECMO support between January 2019 and December 2019 were reviewed retrospectively. Medos Deltastream diagonal pump (DP3) system (Medos Medizintechnik AG, Stolberg, Germany) and Sorin Revolution (Sorin Group Italia, Mirandola, Italy) ECMO systems were used during this date range. In case of multiple run of ECMO (MRE), patients were counted only once.

The patients had aortic arch reconstruction, double outlet right ventricle repair, double switch, repair of atrioventricular septal defect, mitral valve replacement, arterial switch, Tetralogy of Fallot repair, Norwood operation, Fontan procedure and unifocalization-central shunt operations.

After initiation of ECMO, the first lactate levels measured were accepted as the initial lactate levels. Before ECMO initiation the last platelet counts measured were considered as the initial platelet counts. 
Lactate clearance was accepted as the time from initiation of ECMO support until the lactate value fell below $2 \mathrm{mmol} / \mathrm{L}$.

\section{Indications:}

ECMO indications were low cardiac output syndrome (LCOS), inseparability from cardiopulmonary bypass (CPB), ECMOcardiopulmonary resuscitation (E-CPR) and hypoxia.

\section{ECMO system and protocol:}

ECMO systems are divided into two groups (Table 1). System 1 consisted of Medos diagonal pump DP3 centrifugal pump, Hilite 800 LT polymethylpentene (PMP) oxygenator (Medos Medizintechnik AG, Stolberg, Germany) and rheoparin-coated arterial and venous circuits. System 2 consisted of Sorin Revolution centrifugal pump, Liliput 2 PMP oxygenator (Sorin Group Italia, Mirandola, Italy) and phosphorylcholine coated arterial and venous circuits $^{1}$. Depending on the patient weight, we used a pediatric sized straight tip or angled metal multi-port venous cannula and a polyurethane artery cannula with a diameter of 8 to $16 \mathrm{Fr}$.

Table I: Systems

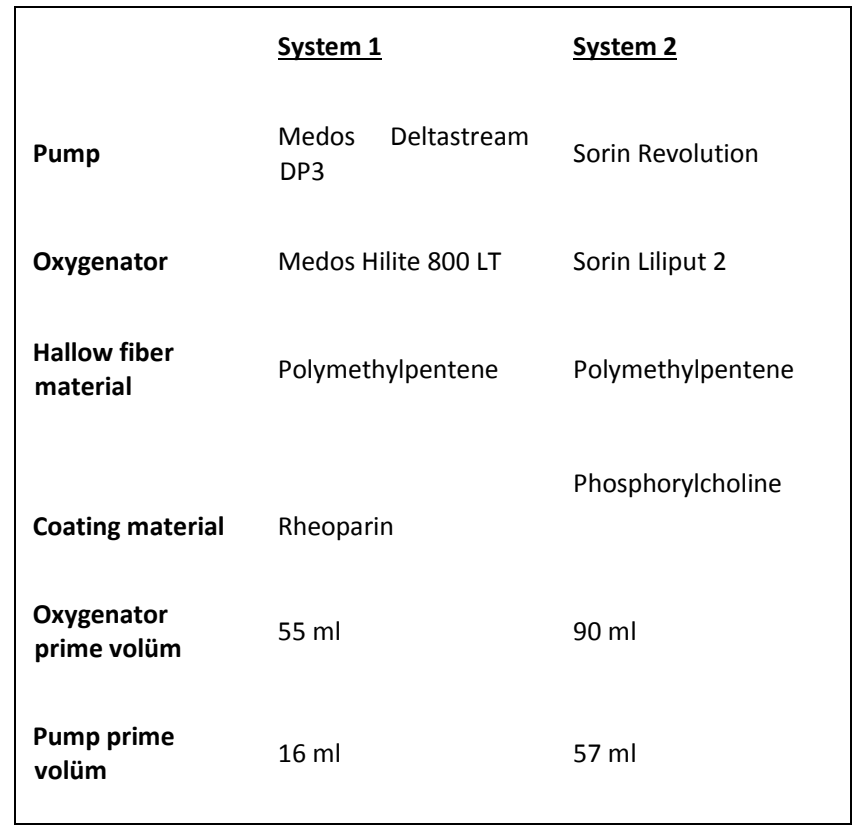

ECMO flow was set at $200 \mathrm{ml} / \mathrm{min}$ for patients weighing $0-3 \mathrm{~kg}, 150 \mathrm{ml} / \mathrm{min}$ for patients between $3.1-10 \mathrm{~kg}, 125 \mathrm{ml} / \mathrm{min}$ for patients between $10.1-15 \mathrm{~kg}$, and $100 \mathrm{ml} / \mathrm{min}$ for patients $>15 \mathrm{~kg}$.

In all patients venoarterial ECMO was used. We used right common carotid artery / internal jugular vein cannulation in patients requiring ECMO support after the 10th postoperative day. Otherwise, right atrium and ascending aortic cannulation was performed. In E-CPR patients circuits were primed with crystalloid, in elective patients were primed with blood. $50 \mathrm{U} / \mathrm{kg}$ of heparin bolus was administered and subsequently the heparin perfusion was started to maintain activated clotting time (ACT) between 180-220. Heparin perfusion were not started for the first 24 hours with the concern about bleeding. Transfusion was performed if hematocrit levels were lower than 30\%, with platelet count lower than $50000 / \mu \mathrm{L}$. We described our ECMO protocol in detail in our previous article ${ }^{4,5}$.

\section{ECMO Weaning:}

In patients with a flow rate of less than $25 \%$ of full flow and adequate myocardial contraction, weaning was started. After providing inotropic and full mechanical ventilator support decannulation was performed. Successful weaning was accepted as patient's survival for more than 48 hours after decannulation. In patients with irreversible organ damage or absence of cardiac recovery, ECMO was terminated.

\section{Complications:}

Classification suggested by the ELSO was used for the identification of complications ${ }^{6}$.

\section{Statistical Analysis}

Statistical analyses were performed using SPSS software. Categorical variables were defined as frequency, while continuous data were expressed as median and interquartile ranges 
for non-parametric continuous variables. For group comparison, Man Whitney $U$ test was used for non-parametric continuous variables, Independent sample $\mathrm{T}$ test for parametric continuous variables; whereas, Chi-Square for categorical data. P-value $\leq 0.05$ was defined as a statistical significance in all analyses.

\section{RESULTS}

Between January 2019 and December 2019, a total of 704 patients were operated and 27 patients (3.8\%) needed ECMO. While 8 (28.5\%) of these patients were successfully weaned, 5 $(17.8 \%)$ were discharged.

Demography, diagnosis, and indications:

The demographic data of the patients are summarized in Table 2. Five (18.5\%) of the patients were neonatal, 14 (51.9\%) were infant and eight (29.6\%) were over one year old. The median weight of the patients was $7.3 \mathrm{~kg}$ (IQR 4.6-11.9). The median weight and the mebody surface area of patients were higher in system 2 group ( $p=0.05)$. It was observed that $59.3 \%$ of the patients were male. Patient diagnoses were classified according to ELSO criteria ${ }^{7}$. Aristotle comprehensive score (ACS), mortality score (MS) and mortality category (MC) were higher in patients System 1. There was no statistically significant difference between the groups in terms of single ventricular physiology ( $\mathrm{p}=$ 0.13).

The ECMO indication was observed as E-CPR in nine patients $(33.3 \%)$, LCOS in six patients (22.2\%), inseparability from CPB in 11 (40.7\%) and ARDS in one (3.7\%). No significant difference was observed between the groups in terms of cannula locations, ECMO duration, reintervention on ECMO, and $\operatorname{MRE}(\mathrm{p}=0.50, \mathrm{p}=$ $0.35, \mathrm{p}=0.13, \mathrm{p}=0.32$, respectively).
Table II: Preoperative demographic variables

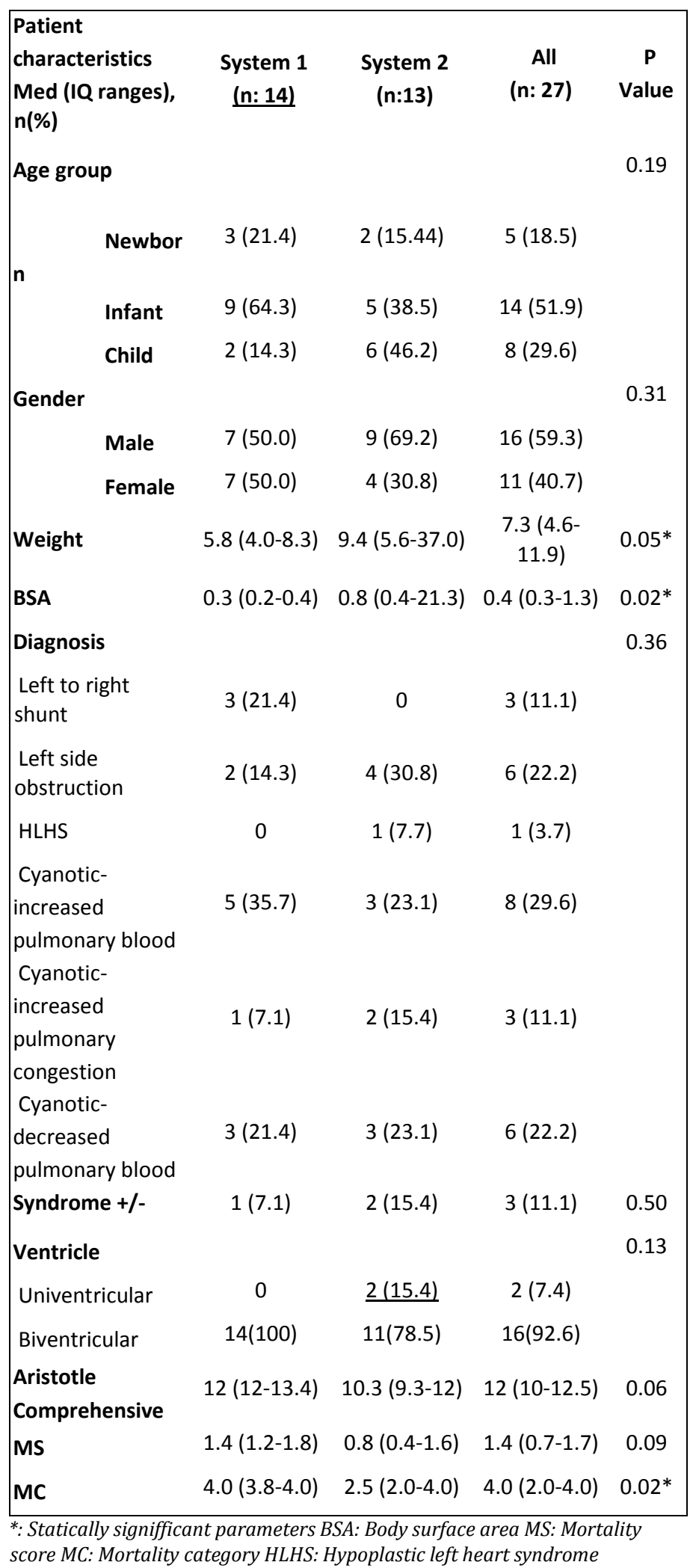


The ECMO indication was observed as E-CPR in nine patients $(33.3 \%)$, LCOS in six patients (22.2\%), inseparability from CPB in 11 (40.7\%) and ARDS in one (3.7\%). No significant difference was observed between the groups in terms of cannula locations, ECMO duration, reintervention on ECMO, and $\operatorname{MRE}(\mathrm{p}=0.50, \mathrm{p}=$ $0.35, \mathrm{p}=0.13, \mathrm{p}=0.32$, respectively).

\section{OUTCOMES}

While successful wean was observed in six (42.9\%) patients in System 1, it was observed as two (15.4\%) in System 2. The number of patients discharged was five (35.7\%) in System 1. It was observed that all of the patients using System 2 died. The difference between the groups in terms of the number of patients discharged was statistically significant $(\mathrm{p}=$ 0.02) (Table 3).

\section{Lactate levels and platelet counts:}

It was observed that the lactate levels at the 8th hour, 12th hour and 24th hours were lower in patients using System 1, but there was no statistically significant difference between the groups $(\mathrm{p}=0.66, \mathrm{p}=0.19, \mathrm{p}=0.19$, respectively). It was observed that the lactate clearance was 14 hours in System 1 (IQR 8-16), 48 hours in System 2 (IQR 21-132) and the difference between the groups was statistically significant $(\mathrm{p}=0.02)$ (Table 4$)$.
Table III: Outcomes and Indications

\begin{tabular}{|c|c|c|c|c|}
\hline $\begin{array}{l}\text { Patient } \\
\text { characteristics } \\
\text { Med (IQ ranges), } \\
\text { n(\%) }\end{array}$ & $\begin{array}{c}\text { System } 1 \\
\text { (n: 14) }\end{array}$ & $\begin{array}{c}\text { System } 2 \\
\text { (n:13) }\end{array}$ & $\begin{array}{c}\text { All } \\
\text { (n: 27) }\end{array}$ & $\begin{array}{c}\mathbf{P} \\
\text { Value }\end{array}$ \\
\hline ECMO indication & & & & $0.02^{*}$ \\
\hline $\mathrm{E}-\mathrm{CPR}$ & $2(14.3)$ & $7(53.8)$ & $9(33.3)$ & \\
\hline $\begin{array}{l}\text { Unsuccessful CPB } \\
\text { weaning }\end{array}$ & $6(42.9)$ & 0 & $6(22.2)$ & \\
\hline $\begin{array}{l}\text { Respiratory } \\
\text { failure (non-PHT) }\end{array}$ & $5(35.7)$ & $6(46.2)$ & $11(40.7)$ & \\
\hline LCOS & $1(7.1)$ & 0 & $1(3.7)$ & \\
\hline Cannula location & & & & 0.50 \\
\hline Central & 13 (92.9) & $11(84.6)$ & 24 (88.9) & \\
\hline Peripheral & $1(7.1)$ & $2(15.4)$ & $3(11.1)$ & \\
\hline ECMO duration & $8.0(5.5-18.8)$ & $6.5(3.8-11.0)$ & $7.0(5.5-12.3)$ & 0.35 \\
\hline $\begin{array}{l}\text { Re-intervention } \\
\text { and/or } \\
\text { reoperation on } \\
\text { ECMO }\end{array}$ & 0 & $2(15.4)$ & $2(7.4)$ & 0.13 \\
\hline MRE & $3(21.4)$ & $1(7.7)$ & $4(14.8)$ & 0.32 \\
\hline $\begin{array}{l}\text { Successful ECMO } \\
\text { weaning }\end{array}$ & $6(42.9$ & $2(15.4)$ & $8(29.6)$ & 0.12 \\
\hline Discharge & $5(35.7)$ & 0 & $5(18.5)$ & $0.02 *$ \\
\hline
\end{tabular}

*: Statically signifficant parameters ECMO: Extracorporeal membrane oxygenation E-CPR: ECMO-cardiopulmonary resuscitation CPB: Cardiopulmonary bypass PHT: pulmonary hypertension LCOS: low cardiac output syndrome MRE: Multiple run of ECMO

Table IV: Lactate levels

\begin{tabular}{|lccccc}
\hline Lactate & System 1 & System 2 & All & P \\
$\underline{\text { Initial }}$ & $\underline{4.1(2.1-8.6)}$ & $\underline{6.8(4.6-11.7)}$ & $\underline{5.4(2.5-9.6)}$ & $\underline{0.16}$ & 0.66 \\
$\mathbf{8}^{\text {th }}$ hour & $4.2(2.9-9.8)$ & $6.4(3.2-8.9)$ & $5.6(3.0-8.9)$ & 0.19 \\
$\mathbf{1 2}^{\text {th }}$ hour & $3.1(2.3-4.6)$ & $4.6(2.8-10.3)$ & $3.9(2.4-6.5)$ & 0.19 \\
$\mathbf{2 4}^{\text {th }}$ hour & $2.5(2.2-4.2)$ & $4.0(2.5-5.9)$ & $2.9(2.3-5.4)$ & $17(13-57)$ & $0.02^{*}$ \\
\hline Lactat clearance $(<\mathbf{2 m m o l} / \mathbf{L})$ & $14(8-16)$ & $48(21-132)$ & & \\
\hline
\end{tabular}

\footnotetext{
*: Statically signifficant parameters
} 
Patients using System 1 had higher platelet counts on the first, second and third days, but there was no statistical difference between the groups $(\mathrm{p}=0.30)$ (Table 5$)$.

Table V: Thrombocyte counts

\begin{tabular}{|lcccc|}
\hline Thrombocyte & System $\mathbf{1}$ & System 2 & All & P \\
Initial & $284 \pm 146$ & $225 \pm 136$ & $255 \pm 141$ & 0.30 \\
$\mathbf{1}^{\text {st }}$ day & $102(29-160)$ & $46(28-101)$ & $51(29-120)$ & 0.38 \\
$\mathbf{2}^{\text {nd }}$ day & $81(33-97)$ & $29(21-50)$ & $47(24-83)$ & 0.08 \\
$\mathbf{3}^{\text {rd }}$ day & $40(36-54)$ & $35(17-76)$ & $40(24-62)$ & 0.66 \\
\hline
\end{tabular}

\section{Complications:}

In one patient (7.7\%) in the Sorin ECMO group, total obstruction of the ECMO system were observed. No mechanical complications were observed in System 1. Hemorrhagic, neurological, renal complications were higher in System 2. However, no statistically significant difference was observed between the groups in terms of complication development (Table 6).

Table VI: Complications

\begin{tabular}{|c|c|c|c|c|}
\hline $\begin{array}{l}\text { Complication } \\
\text { n (\%) }\end{array}$ & $\begin{array}{l}\text { System } 1 \\
\text { (n: 14) }\end{array}$ & $\begin{array}{c}\text { System } 2 \\
(\mathrm{n}: 13)\end{array}$ & $\begin{array}{c}\text { All } \\
\text { (n: 27) }\end{array}$ & $\begin{array}{c}P \\
\text { Value }\end{array}$ \\
\hline Mechanical & 0 & $1(7.7)$ & $1(3.7)$ & 0.29 \\
\hline Hemorrhagic & $5(35.7)$ & 7 (53.8) & $12(44.4)$ & 0.34 \\
\hline Neurological & 0 & $1(7.7)$ & $1(3.7)$ & 0.29 \\
\hline Renal & & & & 0.20 \\
\hline Peritoneal dialysis & 8 (57.1) & $10(76.9)$ & $18(66.7)$ & \\
\hline HDF & 0 & $1(7.7)$ & $1(3.7)$ & \\
\hline Pulmonary & 3 (21.4) & $3(23)$ & $6(22.2)$ & 0.72 \\
\hline Cardiac & $14(100.0)$ & $12(92.3)$ & $26(96.3)$ & 0.29 \\
\hline Infection & $6(42.9)$ & $5(38.5)$ & $11(40.7)$ & 0.82 \\
\hline
\end{tabular}

HDF: Hemodiofiltration

\section{Mortality:}

In System 1, it was determined that six (42.9\%) of 14 patients were successfully weaned, and the remaining eight (57.1\%) patients died on ECMO. Five $(35.7 \%)$ of the six patients who weaned from ECMO were discharged and one (7.1\%) of these patients died. In System 1, total mortality was $64.3 \%$.

In System 2, two of the 13 patients (15.4\%) were successfully weaned, and the remaining $11(84.6 \%)$ patients died on ECMO. Two patients who were weaned from ECMO died. In System 2, total mortality was $100 \%$.

\section{DISCUSSION}

We aimed to compare two ECMO systems we used and share our first experiences about the use of the Sorin pediatric ECMO system. Although the body weight, body surface area, and ACS, MS, MC were lower in Sorin ECMO group, the successful wean rate and the number of patients discharged were lower. Also, we observed a complication that we have not encountered before, such as the sudden stop of ECMO circulation due to occlusion of the ECMO system in one patient.

Plasma leakage, which is one of the difficulties encountered during ECMO support, may be due to the pores in the oxygenator membrane where gas exchanges. Both Sorin and Medos oxygenators are made of non-porous PMP membrane. Studies are reporting that there is 
less plasma leakage from the PMP membrane ${ }^{2}$. However, we observed more plasma leakage in the patient using Sorin ECMO.

Another important problem is hemolysis. Hemolysis occurs due to mechanical stress. It can also be due to thrombosis related consumption coagulopathy. It is also reported that high inlet pressures can cause hemolysis ${ }^{8}$. Lou et al. compared a group of oxygenators, including Liliput 2 and Hilite LT pediatric oxygenators, for the occurrence of hemolysis. While hemolysis was not observed in $33.3 \%$ of patients using Hilite LT oxygenator, only 1.5\% of patients using Liliput 2 oxygenator was not observed. They also reported the use of Liliput 2 and Quadrox D oxygenators, high pump speed (> $1000 \mathrm{rpm}$ ) and high inlet pressure as risk factors for hemolysis 9 .

Another problem is thrombosis. Hastings et al. examined the Sorin Revolution centrifugal pump and they reported that at the top of steel bearing there is an exposed piece that caused thrombosis ${ }^{10}$. Indeed, we observed that in a patient using Sorin ECMO, mechanical circulation suddenly stopped, and this may be due to pump thrombosis. We did not observe any mechanical complications in the Medos ECMO system. Another important point in terms of thrombosis is whether the lines are covered with anticoagulant materials. While Sorin ECMO system is covered with phosphorylcholine, Medos ECMO system is covered with rheoparin. In a study comparing the effectiveness of these two coating materials, were shown to be equal ${ }^{3}$. Although there was no statistically significant difference between the platelet values in our study, it was found that the platelet values were lower on the first, second and third days in the Sorin ECMO group.

Lactate levels are important to follow-up adequate perfusion on ECMO support and has been reported that fluctuation in lactate levels may be associated with mortality ${ }^{11,12}$. Some publications are reporting that lactate clearance is more reliable than the lactate level $(13,14)$. In our study, the 8th hour, 12th hour and 24th hour lactate levels were higher in the Sorin ECMO group, but the difference was not statistically significant. However, lactate clearance was 14 hours in Medos ECMO group, while it was 48 hours in Sorin ECMO group and the difference was statistically significant. However, in the Sorin ECMO group, the number of E-CPR and reoperation was higher, although not statistically significant. This may have an impact on mortality and lactate clearance.

\section{Limitations}

Our patients population is not homogeneous and our study is retrospective single-center study. There is need for studies on large and more homogeneous patients population.

\section{CONCLUSION}

In this study, in which we shared our first experiences regarding the first use of the Sorin ECMO system in the postcardiac pediatric patient group, we observed slower lactate clearance, lower successful wean and higher mortality rates. Therefore, this should be taken into account during the use of this system.

Ethics Committee Approval: After approval of the ethics committee (permit no: 140919 date: 30.01.2020), 27 consecutive patients under 18 years of age who underwent an operation for congenital heart disease and needed ECMO support between January 2019 and December 2019 were reviewed retrospectively.

Declaration of Conflicting Interests: The authors declare that they have no conflict of interest.

Financial Disclosure: No financial support was received.

\section{REFERENCES}

1. Undar A, Wang S, Arda Ozyuksel A, Rossano JW. Pediatric devices. In: Gregory SD, Stevens MC, Fraser 
JF. Mechanical Circulatory and Respiratory Support. London: Academic Press. 2017: 271-97.

2. Thiara AP, Hoel TN, Kristiansen F, et al. Evaluation of oxygenators and centrifugal pumps for long-term pediatric extracorporeal membrane oxygenation. Perfusion. 2007; 22: 323-6.

3. Böning A, Scheewe J, Ivers $\mathrm{T}$, et al. Phosphorylcholine or heparin coating for pediatric extracorporeal circulation causes similar biologic effects in neonates and infants. J Thorac Cardiovasc Surg. 2004; 127: 1458-65.

4. Yildiz O, Haydin S, Ozturk E, et al. Initial Clinical Experiences With Novel Diagonal ECLSSystem in Pediatric Cardiac Patients Artificial Organs 2017; 41: 717-26.

5. Ergün S, Yildiz 0 , Güneş $M$, et al. Use of extracorporeal membrane oxygenation in postcardiotomy pediatric patients: parameters affecting survival. Perfusion. 2020 jan. https://doi.org/10.1177/0267659119897746

6. ELSO: Registry of the Extracorporeal Life Support Organization. Ann Arbor. Available at: (https://www.elso.org/Registry/SupportDocumen ts/ECLSComplicationsCode.aspx).

7. ELSO: Registry of the Extracorporeal Life Support Organization. Ann Arbor. Available at: (https://www.elso.org/Registry/SupportDocumen ts/ICD10DiagnosisCodes.aspx).

8. Pedersen TH, Videm V, Svennevig JL, et al. Extracorporeal membrane oxygenation using a centrifugal pump and a servo regulator to prevent negative inlet pressure. Ann Thorac Surg. 1997; 63: 1333-39.

9. Lou S, MacLaren G, Best D, Delzoppo C, Butt W. Hemolysis in pediatric patients receiving centrifugal-pump extracorporeal membrane oxygenation: prevalence, risk factors, and outcomes. Crit Care Med. 2014; 42: 1213-20.

10. Hastings SM, Deshpande SR, Wagoner S, Maher $\mathrm{K}, \mathrm{Ku} \mathrm{DN}$. Thrombosis in centrifugal pumps: location and composition in clinical and in vitro circuits. Int J Artif Organs. 2016; 39: 200-4.

11. Levy MM. Preface biomarkers in critical illness. Crit Care Clin. 2011; 27: 13-15.

12. Li CL, Wang $\mathrm{H}$, Jia $\mathrm{M}$, et al. The early dynamic behavior of lactate is linked to mortality in postcardiotomy patients with extracorporeal membrane oxygenation support: a retrospective observational study. J Thorac Cardiovasc Surg. 2015; 149: 1445-50.

13. Ryoo SM, Lee J, Lee YS, et al. Lactate level versus lactate clearance for predicting mortality in patients with septic shock defined by Sepsis-3. Crit Care Med. 2018; 46: 489-95.

14. Mungan İ, Kazancı D, Bektaş Ş, Ademoglu D, Turan S. Does lactate clearance prognosticates outcomes in ECMO therapy: a retrospective observational study. BMC Anesthesiol. 2018;18:152. 